\title{
INVESTIGATION WITH LARGE-EDDY SIMULATION OF THE SEA BREEZE REGIMES
}

\author{
Umberto Rizza ${ }^{1}$, Mario Marcello Miglietta ${ }^{1}$, Franciano S. Puhales ${ }^{2}$, Silvana Maldaner ${ }^{2}$, Gervasio \\ Annes Degrazia ${ }^{2}$ \\ ${ }^{1}$ Istituto di Scienzedell'Atmosfera e del Clima, CNR, Lecce, Italy \\ ${ }^{2}$ Departamento de Física, Universidade Federal de Santa Maria, RS, Brasil
}

\section{RESUMO}

Neste trabalho, investigam-se as interações entre a brisa marítima e a turbulência sobre a Terra empregando uma simulação dos grandes turbilhões (LES). Os resultados mostram que o modelo LES é capaz de similar um regime de brisa Mar-Terra-Mar.

\section{INTRODUCTION}

The sea breeze systems occur at coastal locations all over the world and consist of many spatially and temporally nested phenomena. Cool marine air propagates inland as a consequence of a cross-shore mesoscale pressure gradient created by the daytime differential heating. It is a complex phenomenon, which can be modified by many processes at different scales, such as the synoptic forcing, the morphologyof the coastline and the orography, turbulence and cloud cover. A realistic simulation of the sea-breeze would require a model that can simulate both the mesoscale sea-breeze circulation and the small scale turbulent convective boundary layer that is developed over the heated land. A powerful tool for investigating the physics and dynamics of the changing gravity currents in the atmosphere is the large-Eddy Simulation (LES) numerical model. Recently, it was successfully applied to sea-breeze analysis (Antonelli and Rotunno, 2007).

Our objective is to investigate the interactions between the sea breeze and the convective turbulence overland. To achieve this purpose the LES numerical domain has been implemented using a configuration including sea surface everywhere, apart from a small region in the centre of the domain, in order to emulate the topography of the Salento peninsula. The forcing and initial parameters for each sector have been extracted from a mesoscale simulation in which a numerical breeze has been simulated with the model WRF. 


\section{WRF AND LES SETUP}

The Salento peninsula is located in south-eastern Italy and separates the southern Adriatic Sea from the northern Ionian sea. The topography is nearly flat, and the region is influenced from spring to fall by complex sea-land breeze systems, caused by an intense diurnal heating cycle. The period simulated with the WRF model lasts from 5 July 2005, 00 UTC to 8 July, 18 UTC and was characterized by a leveled pressure field and stable weather conditions. The LES domain that is $(30,30,2) \mathrm{km}$ is configured as in figure 1a. The land portion (sector-2) has an extension of $6 \mathrm{~km}$, while the other two sectors (1 and 3), which correspond with the two seas, have an extension of $12 \mathrm{~km}$. In table I the setup parameters for the LES domain including sectors are shown.

\begin{tabular}{|l|l|l|l|}
\hline & $(\mathrm{Nx}, \mathrm{Ny}, \mathrm{Nz})$ & $\begin{array}{l}(\mathrm{Lx}, \mathrm{Ly}, \mathrm{Lz}) \\
(\mathrm{km})\end{array}$ & $\begin{array}{l}\mathrm{z}_{0} \\
(\mathrm{~m})\end{array}$ \\
\hline Domain & $(256,256,128)$ & $(30,30,2)$ & - \\
\hline $\begin{array}{l}\text { Sector }-1 \\
\text { (sea) }\end{array}$ & $(256,102,128)$ & $(30,12,2)$ & 0.0001 \\
\hline $\begin{array}{l}\text { Sector }-2 \\
\text { (land) }\end{array}$ & $(256,52,128)$ & $(30,6,2)$ & 0.1 \\
\hline $\begin{array}{l}\text { Sector -3 } \\
\text { (sea) }\end{array}$ & $(256,102,128)$ & $(30,12,2)$ & 0.0001 \\
\hline
\end{tabular}

Table I: Setup of the LES domain including sectors.

The land (sector-2) and sea (sectors 1-3) features of the surface are characterised by different values of the surface heat flux (figure 1b) and surface roughness.

\section{RESULTS AND DISCUSSION}

Time integration of LES was carried out until the surface heat flux has sufficiently heated the sector- 2 of the domain. In figure $1 \mathrm{c}$ the $(\mathrm{u}, \mathrm{v})$ field is shown at the first vertical point of the LES domain together with the potential temperature field taken after 9 hours of simulation time. It may be easily observed the formation of a breeze front along the lower shoreline. Figure 1d shows a vertical $(x, z)$ cross section of the $(v, w)$ field. In figure 2, a cross-wind (x-z) zoom of the wind/temperature fields around the shoreline is shown in the 


\section{ciênciaenatura}

lowest $500 \mathrm{~m}$ of the LES vertical domain. This figure makes evident that the zero-velocity boundary (figure 2a) is different from the thermodynamic boundary (figure $2 \mathrm{~b}$ ) as already marked by Sha et al (1991). A raised head of frontal type (figure 2a) forms at the leading edge of the current (dotted box inside figure 2a). The front is characterised by a strong vertical velocity whose magnitude is between $2-3 \mathrm{~m} / \mathrm{s}$. Figure $2 \mathrm{~b}$ also depicts the intrusion of colder marine air landward during the sea breeze circulation.

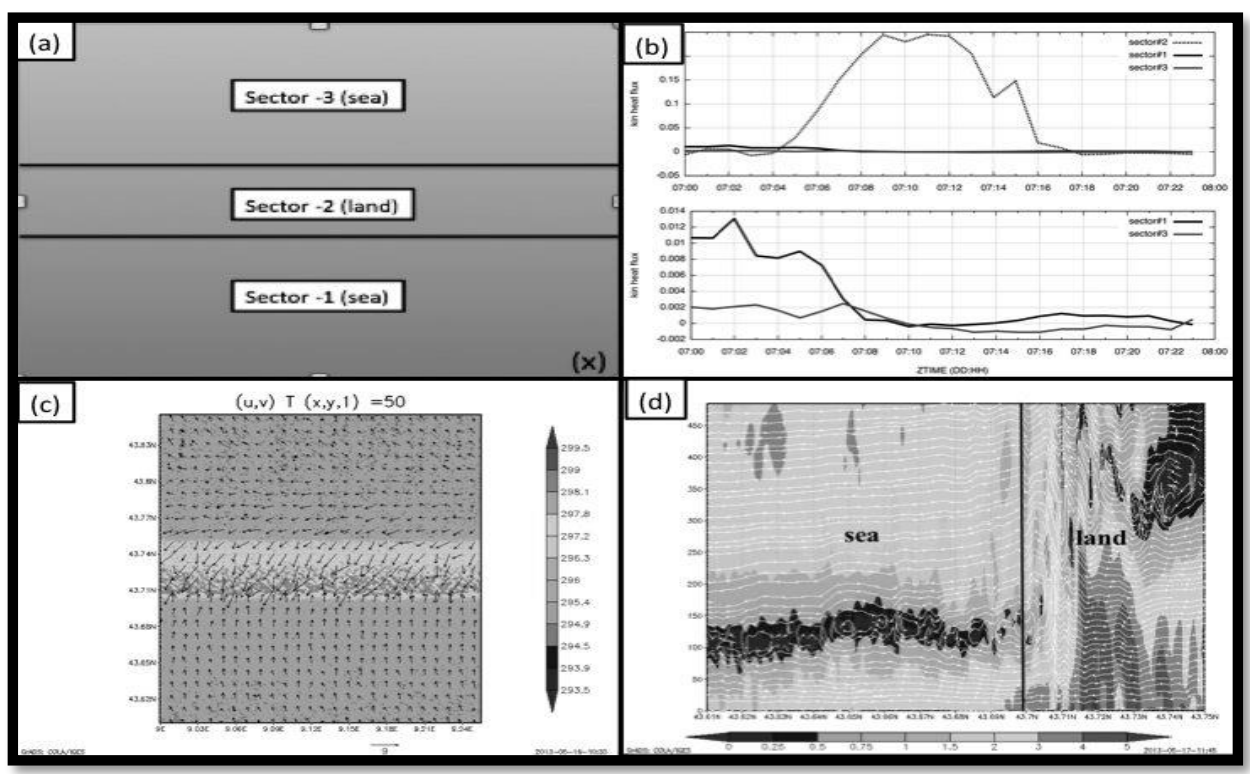

Figure 1: (a) configuration of the domain; (b) sensible and latent heat fluxes; (c) horizontal cross section of surface ( $u, v)$ and temperature field; (d) shows a vertical $(x, z)$ cross section of the $(v, w)$.

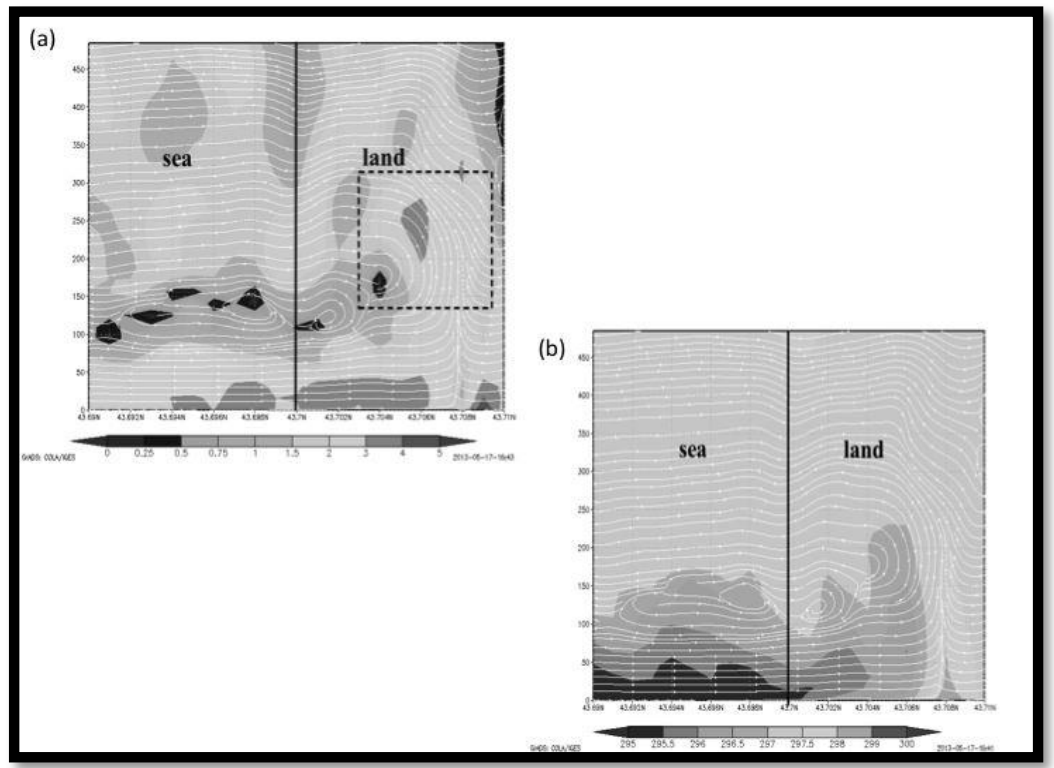

Figure 2: Vertical cross section of ( $v, w)$ field (a) and temperature field (b). 


\section{CONCLUDING}

In this preliminary work, a breeze current is simulated with LES considering a sea-land-sea configuration. Forcing parameters and initial conditions for LES are obtained from a mesoscale simulation in a Mediterranean peninsula in which a complex breeze system is simulated with the model WRF.

\section{REFERENCES}

ANTONELLI, M., ROTUNNO, R. Large-eddy simulation of the onset of the sea breeze.Journal of the Atmospheric Sciences, 64(12), 4445-4457, 2007.

SHA, W., KAWAMURA, T., UEDA, H. A numerical study on sea/land breezes as a gravity current: Kelvin-Helmholtz billows and inland penetration of the sea-breeze front. Journal of Atmospheric Sciences, 48, 1649-1665, 1991. 